\title{
A Role for Authority Supervision in Impact Assessment? Examples from Finnish EIA Reviews
}

\author{
Lovisa Solbär^ \& E. Carina H. Keskitalo \\ Department of Geography and Economic History, Umeå University
}

\begin{abstract}
With the boom in mining in Fennoscandia, reconciliation of competing land use interests in governance procedures such as impact assessment has come to the fore. One of the functions that has been applied to varying degrees in national frameworks is supervision of the procedure by a responsible authority. This paper examines review statements issued in the context of mining project assessments in northern Finland - one of the countries implementing authority supervision. The study shows that third-party review may play a role in highlighting the importance of competing land use interest such as reindeer herding. Attention to such interests, however, remains limited by the application of spatial planning in the case and by consent processing, up until the end of the period examined. Among the lessons for impact assessment is the need for methodologies for accommodating anticipatory types of (practice-based and non-scientific) information. Unless these types of sources are considered valid, the possibility of substantializing anticipation and finding solutions along those lines will be missed, with the risk of making things on the ground worse before the need for mitigation measures is comprehended in the face of materializing impacts.
\end{abstract}

Keywords: environmental assessment; EIA; SIA; mining; reindeer husbandry; Finland Responsible Editor: Øyvind Ravna, UiT- The Arctic University of Norway, Tromsø, Norway.

Received: January 2017; Accepted: March 2017; Published: May 2017

\section{Introduction}

Anticipation of the effects of resource development projects is seen to provide a key means in promoting environmentally and socially sound, sustainable development. Among such policy instruments, the environmental impact assessment (EIA) should facilitate mitigation and prevention of harmful effects at source ahead of realization. ${ }^{1}$ EIA comprises a type of instrument that seeks to stimulate modification of project proposals through the power of information. Hence, knowledge production and the

${ }^{\star}$ Correspondence to: Lovisa Solbär, Department of Geography, Umeå University, Samhällsvetarhuset, 90187 Umeå, Sweden. Email: lovisa.solbar@gmail.com 
integration of different types of knowledge are integral to the procedure, the results of which should then inform the consent decision. ${ }^{2}$ Single-project assessments tend to produce a wealth of information, depending on the breadth of the notion of environment implemented in terms of social, economic, and cultural aspects. ${ }^{3}$ Weighing together different types of impact, EIA professionals are confronted with the challenging task of knowledge integration.

There are two main sources of knowledge on the environment: the first comprises data derived by scientific methodologies and systematic observation of environmental parameters, while the second embraces the practice-based knowledge held by local residents. The involvement of non-scientific knowledge in policy processes is based on insight into its importance to the concerns of environmental governance and to environmental knowledge production. ${ }^{4}$ In keeping with this ambition, the design of assessment procedures as a rule includes deliberative components. This entails the risk of assessments being divided into separate procedural parts, leaving the scientific part responsible for knowledge production and adding deliberations for procedural reasons to satisfy democratic goals. ${ }^{5}$ Besides this problem of knowledge integration, the nature of impact assessment as a procedure separated from decision making - a service function, as it were, to consent processes - introduces a connected problem pertaining to the linkages of assessment practices, the reporting of assessment results and the effectiveness of assessment. ${ }^{6}$

Against this background, the point of departure taken here is the assumption that a well-performed EIA does not only rely on transparency in the presentation of data and interests involved. Besides application of sound assessment methodologies, it also requires an understanding of the expressed viewpoints on their own terms in order to advance their contribution to the assessment at hand. This insight enables questions about at what point during an EIA the meaning of any particular information produced in the process should be understood. As mentioned, extended understandings of knowledge are currently seen as vital to the field of environmental governance. ${ }^{7}$ As argued here, understanding the significance of any practice-based knowledge offered in deliberations must be considered a precondition for such knowledge being well represented along the whole line of assessment and consent processing. With the overall steering of EIA and its application lying with a responsible agency, ${ }^{8}$ we assume that securing the deliberative and integrative tasks must be located here.

The paper aims to examine the steering of EIA procedures by the responsible authority by discussing the review function incorporated into the Finnish EIA - one of the national frameworks that includes pronounced non-coercive supervision of the procedure by a public authority. ${ }^{9}$ In the Finnish application, which only aims at producing information for decision-makers, the responsible agency monitors the process of assessment and evaluates its results. ${ }^{10}$ The tool hereto is verbal and written communication with the developer, other authorities and the interested parties. ${ }^{11}$ Assumedly, this communication is influenced by officials' perceptions of their mandate (objectivity) and role (impartiality, detachment); similarly, their perceptions of particularities at hand are likely to shape the understanding of aspects of importance, which may modify what input from the parties in the process is seen as relevant. ${ }^{12}$ 


\section{Solbär E E. Carina H. Keskitalo}

The quality of the assessment outcomes is crucial regardless of whether the goal of assessment is only informative, e.g. the effectiveness of an EIA has been seen to depend on the extent to which it integrates different perspectives and land-use needs. ${ }^{13}$

The present study is focused on the treatment of reindeer husbandry in the context of the Finnish EIA supervision; thereby, it illuminates the extent to which authority steering could account for the interests of a minor and largely traditional land-use sector. Given the breadth of the institutional scope of EIA frameworks, which is significant even within the EU, appraising the overall implementation of EIA in more depth is difficult. This motivated our focus on a specific case, thus allowing us to see how EIA performs in action. The study is further delimited to examining the written reviews issued by the supervising authority in the context of mining project assessments conducted over the period 1999 to 2015 in the designated Reindeer Herding Area in Northern Finland. Reindeer husbandry as land use comprises a nexus of reindeer, land, and herders, who derive their socio-cultural status and economic outcome from the reindeer. ${ }^{14}$ Representing a challenge to impact assessment, reindeer herding is exposed to multiple impacts, which can be described as depending on the complexity of herding spaces affected by other resource use: Though consisting of physical features, such spaces are also structured by cultural practices and socio-legal systems. Thereby the case also serves to illustrate the complexity of social impacts, or rather, of the interconnections and trigger effects between impact domains usually separated and labelled as social, economic and biophysical. ${ }^{15}$ The paper joins recent crossdisciplinary work ${ }^{16}$ by engaging with resource and environmental policy, spatial planning, land use rights, and legal frameworks of consent processing in an attempt to grasp the variously implicated effects of impact assessment, plan-making and resource use regulation, which ultimately converge in physical settings to support or restrain the feasibility of livelihoods.

\section{Background}

The Finnish Act on Environmental Impact Assessment Procedure (henceforth: Act on EIA) was introduced in 1994 to enact the EU Directives on EIA. ${ }^{17,18}$ The act, as expressed in Section 1, has a dual aim: to promote the assessment of environmental impacts including their consideration in consent processes and to improve public availability of information and public participation. The concept of environment includes social aspects in a broad sense, covering direct and indirect impacts on human health, living conditions and amenity; settlement structure, buildings, rural and urban landscape and cultural heritage; and the utilization of natural resources, besides aspects of nature: the soil, water, air, climate, flora, organisms and biological diversity. The two phases of the procedure concern the plan of assessment (henceforth: Plan) and the results of assessment compiled in a report of assessment (henceforth: Report).

The supervising authority issues a written review on the Plan and eventually on the Report (henceforth: Review). ${ }^{19}$ The Review should provide a nuanced evaluation of the quality and sufficiency of the EIA and direct attention to the key environmental 
characteristics and main effects of the proposal; it should also summarize the viewpoints submitted during deliberations. The Review is to be considered in subsequent processing of the development proposal. ${ }^{20}$ Therefore, as a public assertion, the Review should not be viewed as superficial or matter of routine. Rather the treatment of an issue, be it a species or a local livelihood such as reindeer husbandry, can be taken to stand as an authoritative opinion. Additionally, the authority has to facilitate coordination of the EIA with other legislated procedures. ${ }^{21}$

The duties of the supervising authority offer plenty of contact interfaces that generate opportunities for shaping the procedure. Such duties embrace informing participants, offering feedback on drafts of the Plan and the Report, and coordinating deliberations. These interactions may stimulate changes to the Plan, modify project designs and add issues to be investigated. The process of supervision and the opinion of the supervisory authority thus gain importance in shaping points of intersection between the input from deliberations and the expert-driven environmental studies. Having regional agencies to specialize in EIA supervision may support effective implementation and good practice of assessment, at least in the long run. ${ }^{22}$

Research has predominantly focused on the quality and environmental effectiveness of the Finnish EIA and the degree of institutionalized linkages to decision making. The supervisory function features exclusively in governmental evaluations that also deal with issues such as the implications of the devolved system of regionallevel responsible authorities and the education of administrative personnel. ${ }^{23}$ The evaluations underline the importance of the Review being explicit, revealing assumptions and presenting the totality of viewpoints submitted. ${ }^{24} \mathrm{~A}$ recent study of Reviews in peat production and mining project EIAs suggests that the potential of the Review to support transparency is seldom utilized, rather the origin of viewpoints or sources of information are mostly omitted, which also left the opinion of the reviewer unclear. ${ }^{25}$

\section{Material and method}

The study material is derived from all five mining projects that have been submitted to EIA in the Finnish Reindeer Herding Area. These cases embrace a total of twenty Reviews issued by the supervisory authority in the region of Lapland. ${ }^{26}$ The projects include two realized mines, a gold mine (Kittilä) and a nickel-copper mine (Kevitsa), and three mine proposals: Suhanko: PGM, gold, copper, nickel, Sokli: phosphate, niobium, and Hannukainen: iron, gold, copper (Fig. 1). Production started in Kittilä in 2009 and in Kevitsa in 2012. ${ }^{27}$

The study further draws on interviews with officials at the supervisory and mining authorities $(n=5)$, EIA consultants $(n=4)$, and spatial planners $(n=2)$ as well as minutes from assessment-related meetings sourced from interviewees. Sources of information available for the reviewer were consulted, as well, including special investigations on reindeer husbandry and information contained in viewpoints submitted by representatives of reindeer husbandry. The semi-structured, taperecorded and transcribed interviews were conducted in spring 2015 on the topic of 


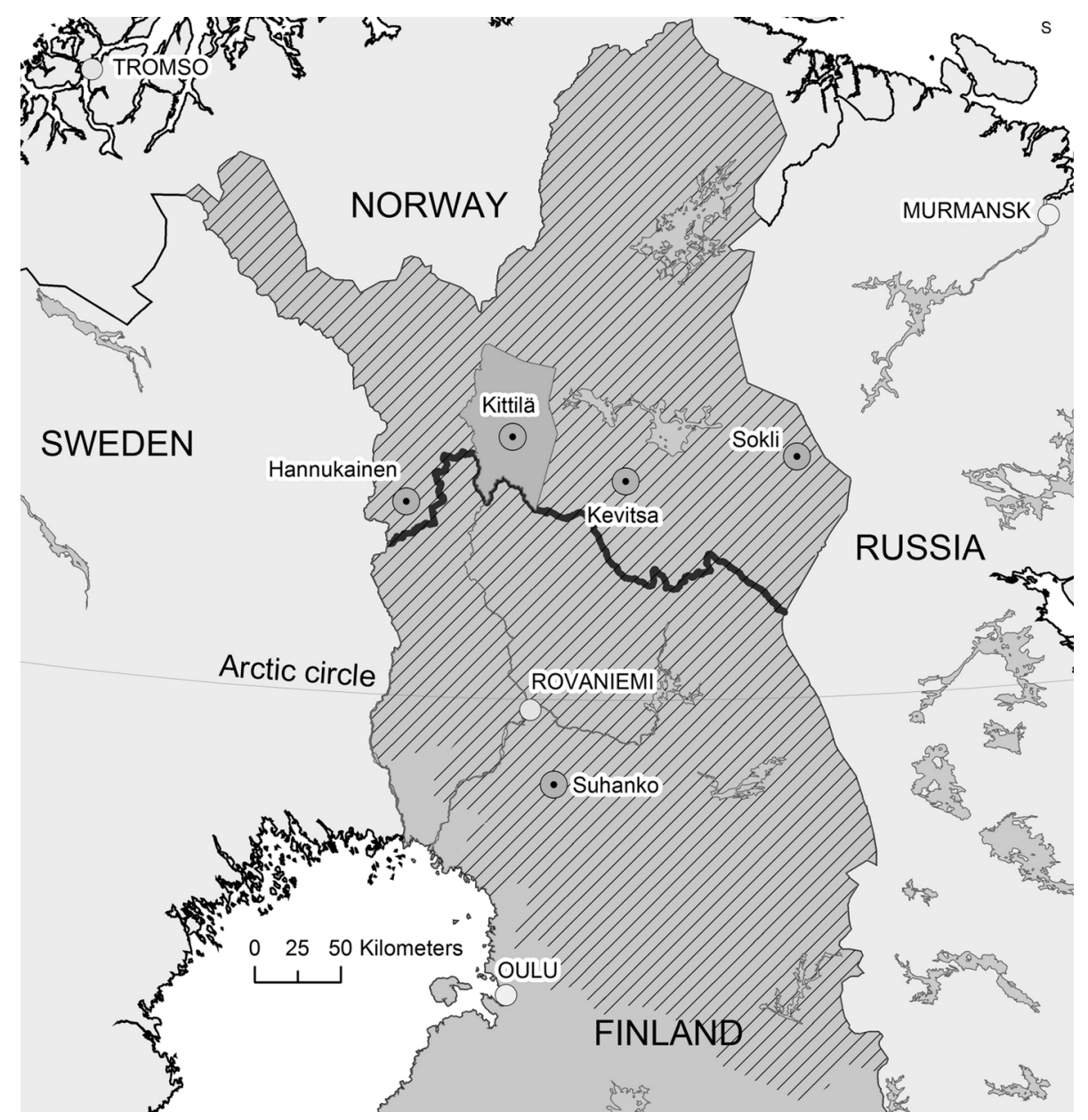

Figure 1. The mining projects studied (circles) are located in the Special Reindeer Herding Area (the black line denotes the southern border of this area), which is a subdivision of the Reindeer Herding Area in Northern Finland (line texture) with the exception of the Suhanko project that is located outside of the Special Reindeer Herding Area in the southern part of the Reindeer Herding Area. The Kittilä Mine lies in the middle of the Reindeer Herding District concerned (polygon). Source: Mikko Jokinen, Natural Resources Institute Finland.

administrative handling of mining projects and re-coded with a focus on the Review. ${ }^{28}$ The first author translated all excerpts presented below.

The treatment of reindeer husbandry in the Reviews was examined using content analysis in terms of quantification of mentions and interpretation of perceptions of the topic signalled by the manner of discussion. ${ }^{29}$ This approach is similar to that used in an earlier Finnish examination of Reviews. ${ }^{30}$

The quantitative examination was conducted on all twenty Reviews (Table 1): Omitting introductory information, the frequency of the word reindeer in the Review proper was counted, including derivations such as reindeer husbandry, reindeer 
Table 1. Written reviews examined. In red, reviews of Assessment Reports. The Adjusted Number of Pages was derived as follows: The number of characters on a filled example page from each review document was divided by the mean of the sum of the corresponding figures of all review documents. This was deemed necessary, as font type and page layout differed across documents.

\begin{tabular}{lllcrrr}
\hline Mine & Target of EIA & Review Issued & No. of Pages & AdjustPages & reindeer & Author \\
\hline Kittilä & Establishment & March 2000 & 7 & 7.1 & 0 & A \\
& & Oct. 2001 & 12 & 11.7 & 2 & A \\
& Expansion I & March 2011 & 6.5 & 6.8 & 4 & D \\
& & Sept. 2012 & 21 & 16.9 & 31 & C \\
& Satellite & May 2014 & 25 & 20.6 & 45 & C \\
& Expansion II & July 2015 & 26.5 & 26.5 & 17 & B \\
Kevitsa & Establishment & March 2005 & 9.5 & 9.7 & 1 & B \\
& Establishment, amended & Feb. 2006 & 5.5 & 5.3 & 2 & B \\
& & June 2007 & 15.5 & 18.7 & 10 & B \\
& Expansion & Oct. 2010 & 17 & 16.4 & 5 & B \\
& & July 2011 & 23.5 & 22.3 & 20 & A \\
Suhanko & Establishment & Feb. 2002 & 7 & 7.1 & 1 & B \\
& & Feb. 2004 & 15.5 & 18.5 & 3 & B \\
& Expansion & April 2013 & 32 & 32.7 & 19 & B \\
& & March 2014 & 48.5 & 48.5 & 27 & B \\
Sokli & Establishment & June 2008 & 13 & 13.2 & 6 & A \\
& & Aug. 2009 & 24 & 27.0 & 22 & A \\
& \multirow{2}{*}{ Amended EIA Report } & April 2012 & 17.5 & 17.3 & 19 & E \\
Hannukainen & Establishment & May 2011 & 30 & 29.6 & 16 & B \\
& & Jan. 2014 & 60.5 & 60.5 & 12 & B \\
\hline
\end{tabular}

herder, etc. (henceforth: reindeer $\left.{ }^{\star}\right)$, but excluding reindeer ${ }^{\star}$ in a heading. The number of pages in the Review proper was noted together with the position of reindeer ${ }^{\star}$ according to topic. In the Finnish language, reference to reindeer husbandry is constructed by using the word stem reindeer; no reference can be made to the matter without using it, with the exception of the term denoting 'reindeer herding co-operative' and 'herding district' (Finnish: paliskunta). Paliskunta is less frequently used $(\mathrm{n}=17)$, as a rule appearing in the same sentence with reindeer ${ }^{\star}(11$ of 17$)$. All sentences containing reindeer ${ }^{\star}$ and, when appearing, subsections on the topic of reindeer husbandry were singled out for further examination. The coding of the contents of excerpts focused on depiction of the activity of reindeer herding, other themes, and rhetorical underlining of the message. This part of the examination was carried out for the Kittilä case with its long time horizon, but a cross-check was made with the Suhanko case that offers temporal spread with regard to the issuing of Reviews (cf. Table 1). The fact that EIA is carried out on the 'same' environment several times, albeit with modifications due to mining, might have influenced the results because subsequent assessments are likely to offer an amalgam of preventive appraisal and documentation of realized impacts. This may distort the process of review in ways that 


\section{Solbär E E. Carina H. Keskitalo}

are difficult to sort out, possibly affecting the frequency of mentions and the treatment of particular issues.

Reindeer husbandry is of cultural and socio-economic importance as a livelihood in northern Fennoscandia. ${ }^{31}$ Its place-bound characteristics expose it to the exclusionary effect of mining, in that its territorial rights are limited to designated herding districts (variously instituted in Norway, Sweden, and Finland). Additionally, given its extensive use of space and seasonal-functional differentiation of lands, a specific herding geography is created, in which all parts play a role. ${ }^{32}$ For this reason, reindeer and herders come to share lands with several other land users and easily experience the accumulation of impacts from a range of resource development projects. $^{33}$

The size and specific localization of mining areas and supporting infrastructures determine the impacts and their severity, depending on the overlaps with functional features such as grazing and calving grounds, rutting and other reindeer gathering areas, reindeer routes and waterway crossings, various lands in reserve and operational areas. Risk prevention and consultation prior to consent and during extractive operations are of particular importance to securing the key features of herding geographies within herding districts. This is stressed in the case of mining, which today increasingly involves breaks and $\operatorname{restarts}^{34}$, calling for safeguarding the post-mining operational ability of remaining land uses.

The task of overseeing mining project EIAs may have been unfamiliar at the beginning of the period covered. The Kittilä project proposal seems to have arrived as a first case on the desk of the responsible authority. ${ }^{35}$ Subsequently during the 2000s, the number of mining project proposals has rapidly risen, as have the actions taken in the wake of this that have embraced legislative reform, policy measures and the production of official guidelines. ${ }^{36}$ The unfolding of the Finnish EIA occurred within a context of large transformations, including the enforcement of new principles that likely place great pressure on the authorities.

\section{Results}

\subsection{Introduction}

The investigation of the Reviews issued by the supervising authority shows that the treatment of reindeer herding undergoes qualitative and quantitative change during the period covered. To start with, this concerns the frequency of mentions. Initially non-existent, the mentions of reindeer ${ }^{\star}$ occur sparsely until around 2008 despite the presence of the topic in the viewpoints submitted by authorities and herding representatives (Table 1; Fig. 2), after which time a marked increase can be noted. Concurrently, reindeer ${ }^{\star}$ mentions spread out into several parts of the Review and individual subsections emerge stressing the topicality of the issue, e.g. for the Kittilä case appearing in 2011. In 2014, the Review concerning the impacts of a proposed satellite mine in Kittilä produces the most extended discussion of the topic in the material, with 45 reindeer* mentions. 


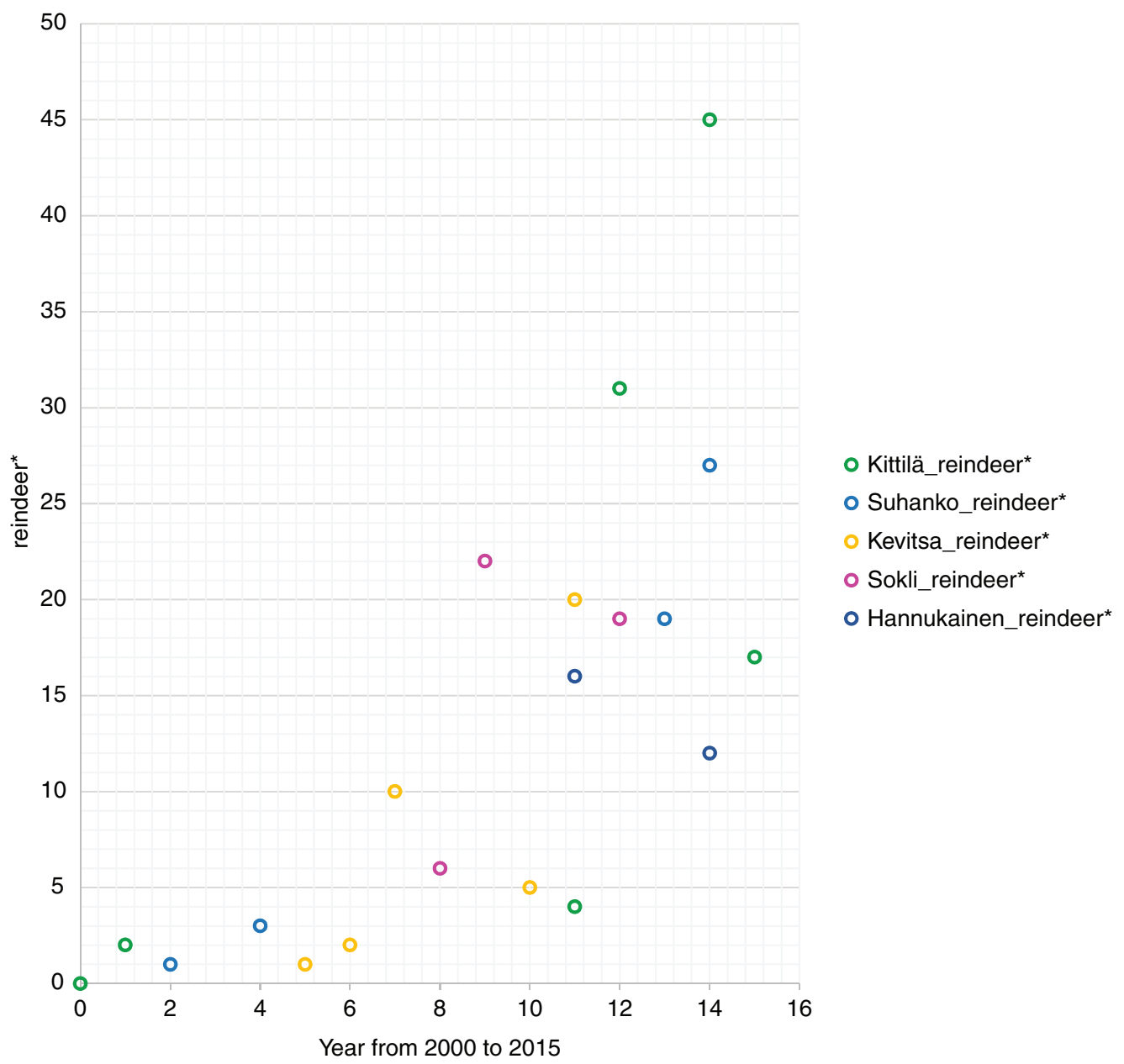

Figure 2. Distribution of the written reviews by year and number of reindeer ${ }^{\star}$ mentions.

Across the period, an overall increase in review length can be observed, presumably reflecting the on-going introduction of parameters to be examined in impact assessment. ${ }^{37}$ In our view, this trend alone does not suffice to render reindeer husbandry an issue of relevance in impact assessment.

At the supervising authority concerned, the review is undertaken by a permanent team of specialists: Among team members, a responsible person is assigned to each assessment case; this person is also tasked with compiling summaries of hearing responses and condensing the input from the team into the Review. ${ }^{38}$ Individual style of expression might influence the length of discussion or the number of reindeer ${ }^{\star}$ mentions. The fact that all Reviews examined have been produced by a single agency should serve to bring out the effect of individual writers. In comparison between cases and authors (Table 1, authors A-E), author style would not seem to exert an influence on length of the Review or on the frequency of reindeer ${ }^{\star}$ mentions. 


\section{Solbär E E. Carina H. Keskitalo}

The short 2011 Review has a unique author and the Reviews from 2012 and 2014, rich in reindeer ${ }^{\star}$ mentions, are written by Author C. Author $\mathrm{C}$ appears in these two cases only. Author A and B occur throughout the period, but changes are still observable over time in the length of the Reviews and in the number of reindeer ${ }^{\star}$ mentions (Fig. 3).

The treatment of reindeer husbandry in the Kittilä case shows a distinct progression in nuance. The first mentions are generalizing and applicable to any mining project in the reindeer herding area. This type of mention occurs throughout the period, for example in the 2015 Review:

The hearing responses offer a feasible starting point and basis for the investigation of the status of reindeer husbandry and the assessment of impacts. Reindeer husbandry as a traditional livelihood has significance in the area. Therefore, it is important to appraise and prevent impacts on it. ${ }^{39}$

Successively, the manner of description becomes more detailed and gains casespecific relevance. This is illustrated by the quotes from 2012 and 2014 below, which between each of them display the same kind of progress:

In several contexts, it has been stated that the most significant impacts of the project are those leading to changes in the land use of reindeer herding and the secondary impacts because of the increasing traffic due to expansion of the mine unavoidable traffic-induced casualties among reindeer. ${ }^{40}$

It has been noted in the context of the Kittilä Mine EIA Procedure that the largest impacts of the mine on reindeer husbandry have been the changes to the natural migratory routes of the [name of village] reindeer, the increased traffic and collisions with reindeer. ${ }^{41}$

The latter 2014 Review adds details by introducing the reindeer of a particular village and migratory routes. The 2015 Review finally, despite producing a more compact discussion of the topic with 17 reindeer $^{\star}$ mentions, retains the detail of the previous Reviews.

The materializing impacts seem to underlie the case-specificity displayed; the quote above from the 2012 Review is placed in the Status of the Environment section. In the manner of referencing viewpoints submitted by the herding cooperative, similar change towards detail and case-specificity is observable; later direct citations are being offered as well. ${ }^{42}$ The desktop project of Suhanko reveals similar progress in the treatment of reindeer husbandry from short and sparse to a more in-depth discussion.

The emerging detailed treatment of the issue clearly adds to the explicitness of the discussion, as exemplified by the 2015 Review:

The goal should be to assess the impact of noise on living nature, birds, animals, and on reindeer and their way of life. ${ }^{43}$

Being verbally explicit can be interpreted as a rhetorical device directed at steering the developer, but it does not seem farfetched to argue for an increasing understanding 


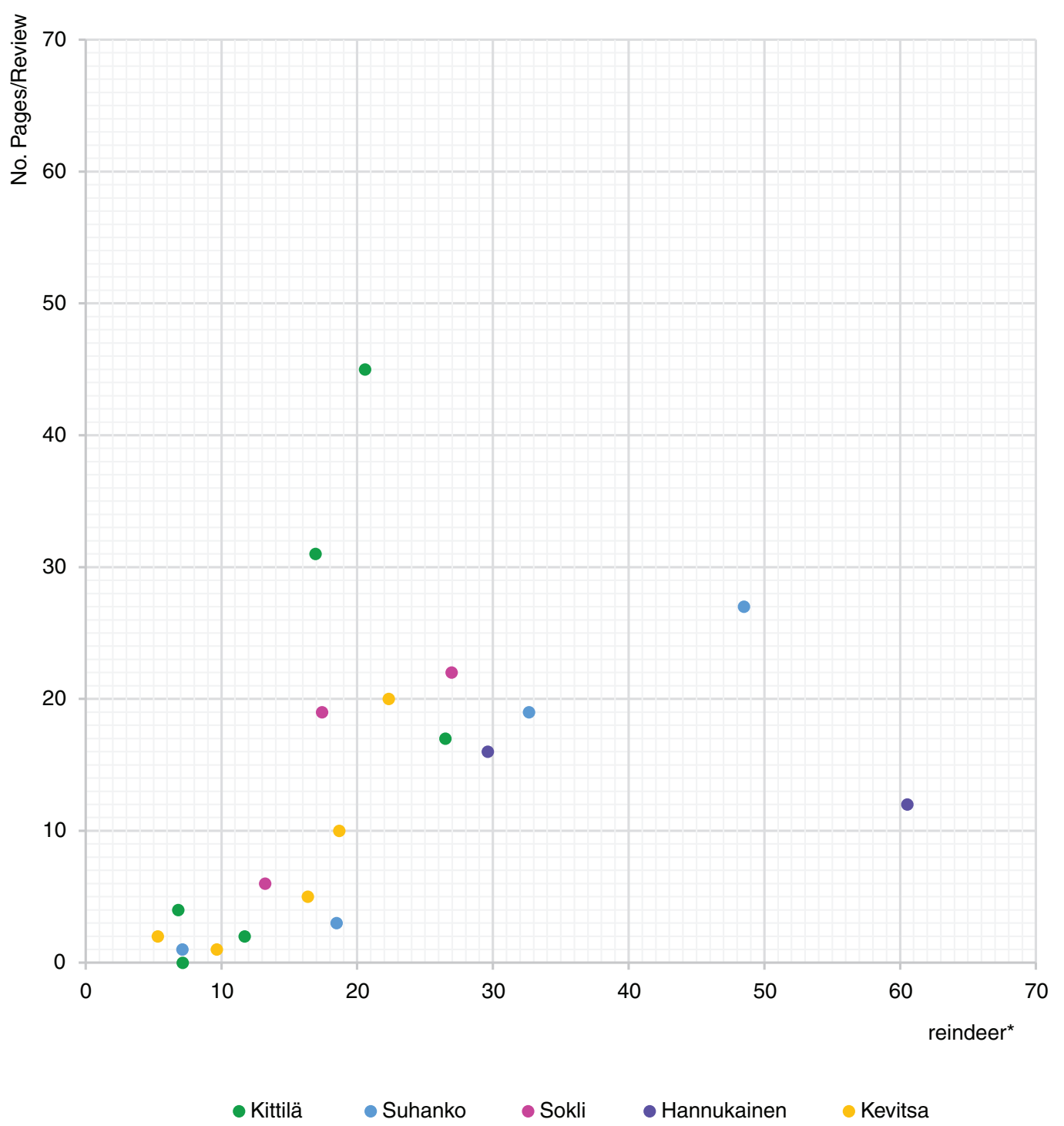

Figure 3. Comparison between number of reindeer ${ }^{\star}$ mentions and number of pages in the written reviews.

of herd management: The internal differentiation of lands in the herding district and cumulativeness of impacts are discussed towards the end of period. ${ }^{44}$ These insights may derive from comprehending the practice-based knowledge submitted in written viewpoints and during field visits. ${ }^{45}$ As we see it, appreciation of issues at stake from a practitioner perspective appears to be a precondition of the advancement of herding matters into an issue of relevance. The attention paid in the Review to bringing out available aspects and multiple viewpoints only emerges over time, and can potentially been seen as resulting from the assessment process. 


\section{Solbär E E. Carina H. Keskitalo}

As a parallel, the linkage between law and the case under assessment only successively becomes an issue worth mentioning. Localization of the project in the Special Reindeer Herding Area (SRA) ${ }^{46}$ is mentioned in the viewpoints submitted in the first round of assessment in 2000. Despite of this, the implications of this fact remain open until 2012, when the Review ${ }^{47}$ requires that stakeholders "be mindful of the Reindeer Husbandry Act when acting in the Reindeer Herding Area". It is first in $2014^{48}$ that the issue is engaged with in more depth, e.g. when it is demanded that the location in the SRA must be "clearly indicate[d]" and "the significance of this for the project [appraised] in legal terms". Such slow acknowledgement of statutory requirements is not in line with what might be expected: Among the review tasks, given the localization of the mine in the SRA, is to safeguard the interests of reindeer husbandry as provided by the act. At this point in time and with manifest impacts of mining on reindeer, the supervisory authority now seems concerned with the possibility of the impacts approaching the level of 'significant hindrance', as designated in the Reindeer Husbandry Act of 1990, Section 2.2 - an issue unsettled in practice. ${ }^{49}$ This concern can be inferred from the passive type of reference in the 2014 Review, ${ }^{50}$ which consists of citing the formulation in the act, "land use in the area may not significantly hinder reindeer herding". But an interview with the EIA authority supports this line of interpretation (emphasis added):

What I find interesting here is the [wide] extent, to which the reindeer herding cooperative utilizes the area and actually the whole area locates in the Special Reindeer Herding Area and mining may not... they should be matched together so that it may not. . . what was the actual wording?. . significantly disturb, so then. . . ...) obviously the migratory routes of the reindeer have changed since mining started, previously they moved along the [name of river] on the same side where the mine is currently located and now this moving is impossible as there are these drainage fields... very wet, so the reindeer do not anymore... their natural migratory routes have been altered due to the mining. ${ }^{51}$

The first part of the quote deserves attention on its own right, as it underlines the learning aspect, 'what I find interesting here', discussed above. In the remainder, the interviewee ponders on what has happened in and around the mining area from the perspective of reindeer husbandry, attempting to remind herself of the wording in the act. In this regard, the EIA Authority should be among the prime institutions to advance clarification of the matter. Indeed, the 2014 Review proposes discussing the issue during the legislated consultations with reindeer herders that are to be held in any instance of operating on state-owned land in the Reindeer Herding Area. ${ }^{52}$ Additional impacts, anticipated prior to development in viewpoints and only mentioned by the Review when manifest, concern the observed avoidance behaviour in a significant radius around the mine.

In sum, we propose an interpretation of the progress found concerning the treatment of reindeer husbandry along two lines: First, learning to understand herding practice constitutes a process. Second, a growing concern about the risk that the impacts of mining will impose a significant hindrance on the operation conditions 
of reindeer husbandry alerts the reviewer to discuss the effects of mining and the needs of reindeer herding. In what follows, we offer our interpretation of the background for this progress in the linked procedures of spatial planning and mining consent processing. However, we start with reasons internal to the assessment itself.

\subsection{Aspects internal to the practice of impact assessment}

The supervisory authority and the main reviewer have wide access to sources of information that embrace at least the environmental information under preparation in draft Reports, informal contacts with the developer, viewpoints submitted, statutory or other criteria of quality, and implementation guidelines. With no changes, as far as we can see, in the matter itself during the period examined, neither on the ground nor in law, the absence or the presence of the current topic may rather depend on a variety of aspects. Among aspects previously found to be of importance are information uptake and choices in the case, ${ }^{53}$ perceptions of good quality in assessment and proper authority guidance, ${ }^{54}$ and perceptions of the function of the Review in consent processing ${ }^{55}$. What is usually included in an EIA may influence the choices; once a method or species has been included, the reviewer is likely to demand the same be done next time. ${ }^{56}$

The initial silence of the reviewer on the topic might read as acceptance of what looks like a judgement of superficiality based on a particular kind of territorial appreciation. For example in the process of mine establishment in the Kittilä case, the Plan and the Report convey the impression of an issue of minor importance and no relevance to the EIA. Such a perception can be inferred from the portrayal of the land to be developed into a mining site as "lacking any particular use" description simply replicated after the conducted assessment ${ }^{58}$ with the addition of information specifying that the mining area consumes $.3 \%$ of the herding district. ${ }^{59}$ The Reviews on these documents offer to the readership no clue as to whether or not the reviewer seconds such an argumentation, which underlines the point that a review cannot be written using the approach 'nothing to add ${ }^{60}$. The later, more detailed and insightful treatment of the issue signals a departure from the perception of territorial insignificance towards demanding that the entire herding district be treated as an impact area and comprehending the operational functionalities of the land use of reindeer herding.

In our view, understanding and learning in the administration are likely to have been be supported by the succession of assessments directed at the same environment. Engagement with the site includes field visits, and materializing impacts make the case more clear-cut - a type of gain that may not benefit the single case, but that may precipitate elsewhere or later. ${ }^{61}$ In addition, in general terms, an increasing number of EIAs and intensifying advisory activity may have supported the progress. It seems that reindeer herding is better understood by the authorities today than in the past, according to representatives of the Reindeer Herders' Association, who point out the special investigation on reindeer husbandry conducted for the Sokli case in 2009 as pioneering and decisive for raising awareness. ${ }^{62}$ 


\section{Solbär E E. Carina H. Keskitalo}

Interestingly, the corresponding Review distinguishes itself slightly in comparison with other Reviews in terms of frequency of reindeer ${ }^{\star}$ mentions (cf. Fig. 2). Further importance is assigned to a report reworking practitioner knowledge into a descriptive guide for impact assessment: ${ }^{63}$ Previously, each new consultant or official had desired the 'same information' over again. ${ }^{64}$ The preparation of this report commenced by the end of 2011, with officials from the supervising authority participating in the work; in late 2012, drafts were circulated for comments. This covers the period when the progress in the treatment of reindeer husbandry in the Reviews becomes particularly evident. The special investigation on reindeer husbandry in Kittilä prior to mine expansion falls into this period, too, this report being completed in March 2012. The advisory input may have served as an eyeopener with regard to herding practice; for example, the 2014 Review of assessment results in the Hannukainen case offers the following discussion:

The loss of reindeer grazing lands presents about $1 \%$ of the herding district's area. Despite such a low figure, the localization of the project in a key area from the point of view of reindeer husbandry results in a significant impact for the herding unit. ${ }^{65}$

How the matter is understood plays a role in the extent to which the impacts of development become perceivable. Thus, consideration of the interests of reindeer husbandry may preclude looking at space in novel ways, as proposed earlier ${ }^{66}$ and, what is more, the how of deliberation appears to stand out as a major issue for effective resource governance. ${ }^{67}$ The question remains why receptivity for this kind of information did not exist earlier, or even ahead of development, and why hands-on guidance of the supervising authority itself appears necessary. Comprehensive information on the assessment of social impacts, among other impacts on livelihoods and land use, was made available in 1999, pinpointing the existence of indirect and cumulative forms of impact and stressing that specific areas and population groups may be particularly vulnerable to these impacts. ${ }^{68}$

\subsection{Post-assessment linkages}

Aspects internal to assessment practice are one side of the coin. The information produced during assessment and the relevance of issues as stated by the Review are both sources of knowledge for post-assessment consent processing. The recent reform of mining law may affect the treatment of reindeer husbandry in mining EIAs. This case also serves to explicate the importance of institutionalized linkages to decision making, as will be discussed below. Another aspect likely to influence the treatment of the topic is what we found to be an explicit link between the procedures of EIA and spatial planning. ${ }^{69}$ These procedures often advance synchronously, as both work from the pre-development point of view and include deliberations and investigations of the area targeted. Evidence suggests, however, that the EIA is even expected to supplement for otherwise lacking public hearings, a situation called forth in the Kittilä case by the non-implementation of regular spatial planning. ${ }^{70}$ The increased mentions, especially the citing of viewpoints submitted by reindeer herders, may seek to remediate this. Here, the lack of plans to settle land-use issues 
at the comprehensive and detailed levels derives already from the mining establishment phase and has been perceived as a weak administrative ground for handling mine expansions. ${ }^{71}$ Such 'light' approaches to clarifying land-use issues, while legally acceptable, are associated with vague guidance and unclear implications, ${ }^{72}$ and may rather support the applicant and discriminate others' needs and participation in decision making, not least due to the absence of a formal demand to consider submitted viewpoints. ${ }^{73}$ Given the choice of this institutional path, the risk of continued application of more of the same is evident, as realized in the Kittilä case.

Whether or not the characterized supplementary function between assessment and spatial planning is as explicit in the other cases examined remains an open question, but we observe that, during 2000-2015, plan-making in the context of mining projects seemed to move towards more comprehensive solutions. In the context of the later projects of Sokli, Hannukainen, and the expansion of Suhanko, regular land-use plans have been produced. In contrast, the case of Kevitsa, too, was settled by adopting to a lighter planning solution backed-up by an out-dated master plan. ${ }^{74}$ Generally, the relationship of spatial planning and EIA is weakly regulated in the Act on EIA (Section 5: 'shall cooperate sufficiently'), making it an issue to be confronted in each case individually. Research has predominantly focused on whether planmaking is in the position of replacing EIA, ${ }^{75}$ rather than the other way round.

The post-assessment life of a proposal can prompt more detailed treatment of an issue in the EIA in those situations where the opinion of the supervising authority can be taken to have gained more weight in resource consent processing. The recently reformed Mining Act, which came into force on July 1, 2011, demands that provisions be issued in the mining permit for, among other things, mitigation of disturbances to reindeer herding due to mining activities in the SRA. ${ }^{76}$ When taken together with the requirement that the results of the EIA and the Review be explicitly considered and referred to in (processing) the mining consent, ${ }^{77}$ this reform is likely to have implications for the review. ${ }^{78}$ The background to this is that, in the context of extractive projects, issues of resource use and environmental protection are mainly covered by the permitting under the Mining Act, the Environmental Protection Act and the Water Act. ${ }^{79}$ The environmental information produced by the EIA is typically too broad to be subsumed under permit provisions: the environmental permit for example is not in the position of accommodating mitigation of impacts caused by physical alteration of land (by construction work or digging, etc.) unless these were to lead to emissions into the air or water. ${ }^{80}$ An obvious issue of relevance to reindeer herding, construction work may induce difficult-to-anticipate alterations in reindeer behaviour, and ditches or other holes may put the animals at risk. Traditionally, such issues should be solved by non-public two-party agreements between the mining company and reindeer herders.

The reformed process has been seen as offering sufficient scope to consider local knowledge ${ }^{81}$ and to include broad mitigation measures, the need for which may have arisen during the EIA. ${ }^{82}$ In an ideal case, selected permit provisions designed to fit the issues at hand could support the operational needs of the "competing" resource use. These provisions could accommodate, e.g., the effects of physical alterations on land. 


\section{Solbär E E. Carina H. Keskitalo}

For mines in operation, the mining authority is to issue supplementary decisions in this regard.

Enforcement of the reformed mining law seems to correspond with the broadening treatment of reindeer husbandry in the Reviews, including bringing statutory issues to the table. The progress observed appears, in this light, to be an attempt to provide the mining authority with information on likely impacts on reindeer husbandry information that could be used when issuing the aforementioned provisions. The duty of the supervisory authority is to inform post-assessment consent processing about matters of importance and point out the most essential impacts, regardless of the destiny of the issue in the mining administration. While such provisions issued in the cases of Kittilä and Kevitsa bring little with respect to the land-use interests of reindeer husbandry, ${ }^{83}$ with regard to upcoming proposals and considering the progress observable over time, the trend in the treatment of reindeer husbandry in the EIAs can be welcomed. Field evidence indicates that two-party agreements between reindeer herders and developers do not always result in long-term commitment. ${ }^{84}$ For this reason, it would seem to be meaningful to introduce mitigation measures via another channel, such as directly in consent provisions, which could be more secure from this perspective. ${ }^{85}$

\section{Lessons for assessment practice and conclusions}

The findings of the present study point out processes of knowledge formation and environmental learning and awareness in the administration; ${ }^{86}$ that is, the EIA procedure appears capable of offering, at least towards the end of the period investigated, an arena for knowledge integration - a kind of 'boundary organization' that helps to connect realms of knowledge. ${ }^{87}$ The study underlines the previous finding that "this shows that further legislative reform is not required to improve effectiveness but rather a focus on changing the behaviour of individual professionals" ${ }^{\prime 88}$. The types of changes observed here need to propagate further in consent processing; in the case at hand, this concerns the mining permit and the supplementary provisions issued for existing mines in accordance with the reformed mining law. The initial assumption concerning the role of the responsible authority in assigning significance to any particular information produced during the EIA is confirmed by the study. In the main case examined, the series of assessments demonstrates that the EIA is flexible enough a tool to accommodate both the absence and the presence of parameters; over time, the supervising authority makes different choices with regard to either supporting absences or demanding increased presence, e.g., of local viewpoints in the procedure. It is important for the Review to overcome any grading of assessment parameters, e.g., by culturally and socio-economically motivated positioning of livelihoods and land uses - an issue that must be seen to belong to non-rational aspects that may shape impact assessment. ${ }^{89}$

Furthermore, the study underlines the weakening of the anticipatory function of EIA. This can be expected to be true in any instance of reliance on measurable 
changes in the environment, rendering impact assessment a type of ex-post-facto approach rather than a preventive tool. Somewhat ironically, the (positive) outcome produced by the repeated assessments in the Kittilä case seems to do the work of a follow-up: "By incorporating feedback into the EIA process, follow-up enables learning from experience to occur" ${ }^{\prime 90}$. Key issues exposed by the study therefore include the capability of EIA to contribute to preventing damage at source, as a priority in environmental governance. The apparent inability or ignorance concerning taking anticipatory information as a valid source of knowledge bypasses the possibility of suggesting supportive actions to help in substantializing the anticipations made and, during consenting processing, finding solutions along such lines. Moreover, it risks letting things on ground initially worsen before the need for mitigation measures is comprehended in the face of materializing impacts.

Crucial to the ability of the readership (consent authorities and the public) to draw conclusions concerning the opinion of the supervising authority as a 'securer of quality' would then be the degree of explicit reasoning offered, besides stating the general sufficiency and quality of the assessment procedures. This requires high agency capacity, well-developed attention to mainstreaming the operative procedures for assessment and best practice. Lack of knowledge and complicated causalities do not appear to be legitimate reasons for depriving an issue of its relevance for impact assessment; rather, learning options may arise in contact with the practitioners of reindeer husbandry as an example of sources of practice-based knowledge. The study indicates the need to improve the capacity of EIA to consider not only anticipatory information, but also non-scientific types of experiential knowledge. In doing so, it confirms formulations of tasks for EIA $^{91}$ as well as the great requirements placed on the reviewing agency.

\section{ACKNOWLEDGEMENTS}

We are grateful for funding from the MISTRA Arctic Sustainable Development Programme. The authors wish to acknowledge the valuable comments made by the two anonymous reviewers.

\section{NOTES}

1. Barry Sadler, Environmental Assessment in a Changing World: Evaluating Practice to Improve Performance (Ottawa, International Association for Impact Assessment, 1996), http://www. ceaa-acee.gc.ca/Content/2/B/7/2B7834CA-7D9A-410B-A4ED-FF78AB625BDB/iaia8_e.pdf (Dec. 5, 2016); Christopher Wood, Environmental impact assessment: a comparative review (Edinburgh, Pearson, 2003); IAIA, What is Impact Assessment? (Ottawa, International Association for Impact Assessment, 2009), http://www.iaia.org/uploads/pdf/What_is_IA_ web.pdf (Dec. 5, 2016).

2. Ivar Lyhne, Matthew Cashmore, Hens Runhaar and Frank van Laerhoven, "Quality control for environmental policy appraisal tools: An empirical investigation of relations between quality, quality control and effectiveness," Fournal of Environmental Policy and Planning 18 (1) (2016); Einar Eythorsson and Alma Elizabeth Thuestad, "Incorporating traditional knowledge in environmental impact assessment - How can it be done?" Arctic Review on Law 
and Politics 6(2) (2015); Wood, Environmental impact assessment; Bernard Delvaux and Frédéric Schoenaers, "Knowledge, local actors and public action," Policy and Society 31 (2012): 105-117; cf. Kaitlyn J. Rathwell, Derek Armitage and Fikret Berkes, "Bridging knowledge systems to enhance governance of the environmental commons: A typology of settings," International fournal of the Commons 9(2) (2015); Alma Demszky and Armin Nassehi, "Perpetual loss and gain: Translation, estrangement and cyclical recurrence of experience based knowledges in public action," Policy and Society 31 (2012): 179.

3. IAIA, What is Impact Assessment?

4. Ibid.; Rathwell, Armitage and Berkes, Bridging knowledge systems; cf. Helga Nowotny, Peter Scott and Michael Gibbons, Re-Thinking Science. Knowledge and the Public in an Age of Uncertainty (Cambridge, Polity Press, 2001).

5. Matthew Cashmore, Alan Bond and Dick Cobb, "The role and functioning of environmental assessment: Theoretical reflections upon an empirical investigation of causation," Fournal of Environmental Management 88 (2008): 1245; Demszky and Nassehi, Perpetual loss and gain.

6. Ismo Pölönen, "Quality control and the substantive influence of environmental impact assessment in Finland," Environmental Impact Assessment Review 26 (2006); Lauren Tinker, Dick Cobb, Alan Bond and Mat Cashmore, "Impact mitigation in environmental impact assessment: paper promises or the basis of consent conditions?" Impact Assessment and Project Appraisal 23(4) (2005); Stephen Jay, Carys Jones, Paul Slinn and Christopher Wood, "Environmental impact assessment: Retrospect and prospect," Environmental Impact Assessment Review 27 (2007); Lyhne et al., Quality Control.

7. cf. Edward P. Weber, Jill M. Belsky, Denise Lach and Antony S. Cheng, "The Value of Practice-Based Knowledge," Society and Natural Resources 27 (2014).

8. Sadler, Environmental Assessment in a Changing World, 122; ERM, Guidance on EIA, EIS Review (Edinburgh, Environmental Resources Management, 2001), 8, http://ec.europa.eu/ environment/archives/eia/eia-guidelines/g-review-full-text.pdf (Jan. 28, 2016).

9. Kai Kokko et al., Sound Mining in the North. A Guide to Environmental Regulation and Best Practices Supporting Social Sustainability (University of Oulu, Finnish Forest Research Institute and University of Lapland, 2014), http://auda.ulapland.fi/bitstream/handle/ 10024/59503/Sound\%20minig\%20in\%20the\%20North.pdf?sequence=2 (Sept. 28, 2016); Ismo Pölönen, Pekka Hokkanen and Kimmo Jalava, "The effectiveness of the Finnish EIA system - What works, what doesn't, and what could be improved?" Environmental Impact Assessment Review 31 (2011): 123.

10. Eira Ostamo and Mikael Hildén, The Quality of the EIA Authority's Statements: Evaluation of EIA procedures 1994-1997 (Helsinki, Ministry of the Environment, 1998).

Pölönen et al., The effectiveness of the Finnish EIA.

11. Ibid.

12. cf. Mari Kågström and Tim Richardson, "Space for action: How practitioners influence environmental assessment," Environmental Impact Assessment Review 54 (2015); Richard K. Morgan et al., "Practitioners, professional cultures, and perceptions of impact assessment," Environmental Impact Assessment Review 32 (2012).

13. Kokko et al., Sound Mining in the North. See note 9. Pölönen et al., The effectiveness of the Finnish EIA, 125f. See note 9.

14. Hannu I. Heikkinen, "Changing business strategies of reindeer husbandry in Finland", Int $\mathcal{F}$ Business Performance Management 9(3) (2007): 304-309; RHA, Guide to examining reindeer husbandry in land use projects (Reindeer Herders' Association, Rovaniemi, 2014), http:// paliskunnat.fi/reindeer-herders-association/wp-content/uploads/2015/03/PoroYVA_2014_EN_ web.pdf (Jan. 26, 2016).

15. cf. Frank Vanclay, "International Principles for Social Impact Assessment," Impact Assessment and Project Appraisal 21(1) (2003): 5-11. 
16. Gro B. Ween and Marianne E. Lien, "Indigenous land claims and multiple landscapes: postcolonial openings in Finnmark, Norway", in Nature, Temporality and Environmental Management. Scandinavian and Australian perspectives on peoples and landscapes, eds., Lesley Head, Katarina Saltzman, Gunhild Setten and Marie Stenseke (London and New York, Routledge, 2017).

17. Act on Environmental Impact Assessment Procedure 468/1994, http://www.finlex.fi/en/laki/ kaannokset/1994/en19940468.pdf (Oct. 5, 2016).

For descriptions of the Finnish EIA, see Pölönen et al., The effectiveness of the Finnish EIA, Kokko et al., Sound Mining in the North, 21-24; Jorma Jantunen, et al., Guide: Environmental Impact Assessment Procedure for mining projects in Finland (Helsinki, Ministry of Employment and the Economy, 2015); Timo Koivurova et al., Environmental Impact Assessment in the Arctic: A Guide to Best Practice (Cheltenham, Edward Elgar, 2016), 21, 35-39.

18. In this background section, we draw on interviews with EIA consultants and officials at the EIA Authority.

19. Act on EIA, SIS 9, 12.

20. Ibid., $₫ 13$.

21. Ibid., IS 3,16 .

22. Pölönen et al., The effectiveness of the Finnish EIA.

23. Ostamo \& Hildén, The Quality of the EIA Authority's Statements; Pölönen and Halinen, Quality control of the EIA reports; Seija Rantakallio et al., "Improvement of the work of the EIA coordinating authorities," Reports of the Ministry of the Environment 8 (2015), https:// helda.helsinki.fi/bitstream/handle/10138/153636/YMra_8_2015.pdf;sequence=1 (Febr 8, 2016).

24. Ostamo and Hildén, The Quality of the EIA Authority's Statements, 36; Tommi Kauppila, et al., "Good Practices in Assessment of the Environmental Impacts of Mining Projects," Reports of the Geological Survey of Finland 222, http://tupa.gtk.fi/julkaisu/tutkimusraportti/tr 222.pdf (May 23, 2016)

25. Pölönen and Halinen, Quality control of the EIA reports.

26. The Reviews are publicly available at the Joint Website of Finland's Environmental Administration, www.ymparisto.fi.

27. For details on the mining projects discussed, see Hannu I. Heikkinen, Élise Lépy, Simo Sarkki and Teresa Komu, "Challenges in acquiring a social licence to mine in the globalising Arctic," Polar Record 52(4) (2016): 403f.; Timo Koivurova et al., “'Social license to operate': a relevant term in Northern European mining?", Polar Geography (2015), 14ff.; Leena Suopajärvi, "Social impact assessment in mining projects in Northern Finland: Comparing practice to theory", Environmental Impact Assessment Review 42 (2013): $26 \mathrm{f}$.

28. An additional interview was planned with the supervising authority to discuss the results of the study, but this could not be realized in due time. The EIA Team was approached for respondent validation of the interpretation based on of formulations in the Interview on April 16, 2015.

29. Jouni Tuomi and Anneli Sarajärvi, Laadullinen tutkimus ja sisällönanalyysi [Qualitative Inquiry and Content Analysis] (Helsinki, Tammi, 2009).

30. Ostamo \& Hildén, The Quality of the EIA Authority's Statements, 8.

31. Asta Kietäväinen, "Porotalouden taloudelliset ja työllistävät vaikutukset", Maaseudun uusi aika 1 (2012); Ludger Müller-Wille et al., "Synthesis: Environmental and Sociopolitical Conditions for Modern Reindeer Management in Europe's North", in Reindeer management in northernmost Europe: linking practical and scientific knowledge in social-ecological systems, ed. Bruce C Forbes et al. (Berlin, Springer Ecological Studies 184, 2006); Taru Meristö et al., "Porotalouden tulevaisuus. Keitä olemme ja mitä meille kuuluu?" Kala- ja riistaraportteja 298 (Helsinki, Riista- ja kalatalouden tutkimuslaitos, 2004); Simo Sarkki et al., "SocioNatural Capital for Sustainable Land Use in the Fennoscandia". Arctic Yearbook 2014, 
http://www.arcticyearbook.com/images/Arcticles_2014/Sarkki_et_al_AY_2014_FINAL. pdf (Oct. 4, 2016); Merja Renko and Taru Sutinen. Poroja kahta puolen puuta: tutkimus porotilojen kehityksestä ja toimeentulosta (Rovaniemi, Lapin yliopiston yhteiskuntatieteellisiä julkaisuja, 2006).

32. Müller-Wille et al., Synthesis; Nuccio Mazzullo, "The nellim forest conflict in finnish lapland: Between state forest mapping and local forest living", in Nomadic and Indigenous Spaces: Productions and Cognitions, eds. Judith Miggelbrink, Joachim O. Habeck and Peter Koch (Routledge, Abingdon, 2013), 91-112.

33. Anneli Pohjola and Jarno Valkonen, "Johdanto", in Poronhoitajien hyvinvoinnin uhat ja avun tarpeet, eds. Anneli Pohjola and Jarno Valkonen (Rovaniemi, Lapin yliopistokustannus, 2012).

34. Helka-Liisa Hentilä and Jussi S. Jauhiainen, "Johtopäätöksiä - kohti kestävää kaivostoimintaa paikallistasolla", in Kasvun ja supistumisen ohjauskeinot ja elinympäristön laatu tapauksena pohjoisen Suomen kaivoskunnat, eds. Helka-Liisa Hentilä and Emilia Ihatsu (University of Oulu, 2009), 54-60, http://jultika.oulu.fi/files/isbn9789514291340.pdf (Sept. 30, 2016).

35. cf. Ulla-Riitta Käyhkö, Ismo Pölönen and Elisabeth Grönlund, “Applying the EIA Procedure in individual cases - Quality and coherence of application decisions in 1994-2006", Finnish Environment 18 (Helsinki, Ministry of the Environment, 2007), https:/helda.helsinki.fi/bitstream/handle/10138/38406/SY_18_2007.pdf?sequence=3 (Oct. 4, 2016); LVT, EIA Report (Rovaniemi, Lapin Vesitutkimus, 2001), http://www.ymparisto. fi/download/noname/\%7B839C4D3A-F672-4DBD-8327-A659C948B85D\%7D/43197 (Oct. 4, 2016), 172; Ostamo and Hildén, The Quality of the EIA Authority's Statements; Aila Ryhänen, "Kolme kuntaa, kolme kaivosta," in Kasvun ja supistumisen ohjauskeinot ja elinympäristön laatu: Tapaus Sotkamo, eds. Raine Mäntysalo and Kalle Vahtera, University of Oulu, Publications of the Section of Architecture C 110 (2007), URL http://herkules.oulu.fi/ isbn9514285073.

36. Hannu Hernesniemi et al., "Kalliosta kullaksi, kummusta klusteriksi. Suomen mineraaliklusterin vaikuttavuusselvitys", Research Institute of the Finnish Economy (2011), https://www.etla.fi/ wp-content/uploads/kalliosta kullaksi kummusta_klusteriksi.pdf (Sept. 30, 2016), 137.

37. Joint interview EIA consultants A \& B, April 13, 2015; Interview EIA Consultant C, April 13, 2015; Interview EIA Team, April 16, 2015.

38. Interview EIA Team, April 16, 2015.

39. 2015-Review, 27.

40. 2012-Review, 20.

41. 2014-Review, 25.

42. 2012-Review, 21; ibid.; 2015-Review, 27.

43. 2015-Review, 26.

44. 2014-Review, 12, 25; ibid., 27.

45. Interview EIA Team, April 16, 2015.

46. On the subdivisions of the Reindeer Herding Area, see RHA, Guide to examining reindeer husbandry, 8f.

47. 2012-Review, 20.

48. 2014-Review, 26.

49. Marja Anttonen, Land Use and EIA Consultant, Reindeer Herders' Association, Rovaniemi. Telephone conversations with first author (March 14, 2016; Oct. 4, 2016); Teresa Komu, "Retoriikkaa vai sosiaalista kestävyyttä? Poronhoitoyhteisöjen osallistaminen kaivostoiminnan suunnitteluprosesseissa" (Master Thesis, University of Oulu, 2013).

50. 2014-Review, 26.

51. Interview EIA Team, April 16, 2015.

52. 2014-Review, 11, cf. Reindeer Husbandry Act, $₫ 53$. 
53. Pekka Hokkanen and Matti Kojo, "How environmental impact assessment influences decision-making", Finnish Environment 612 (2003), https://helda.helsinki.fi/bitstream/ handle/10138/40473/SY_612.pdf;sequence=1 (Oct. 4, 2016); Ostamo and Hildén The Quality of the EIA Authority's Statements.

54. Pölönen and Halinen, Quality control of the EIA reports, $64 \mathrm{f}$.

55. cf. Kågström and Richardson, Space for action.

56. Interview EIA Consultant C, April 13, 2015; cf. e.g. Stephanie N. T. Landim and Luis E. Sánchez, "The contents and scope of environmental impact statements: how do they evolve over time?", Impact Assessment and Project Appraisal 30 (2012).

57. LVT, EIA Program (Rovaniemi, Lapin Vesitutkimus, 1999), 13. Printed copy received from the EIA Team.

58. LVT, EIA Report, 34.

59. Ibid., 125.

60. cf. Ostamo and Hildén, The Quality of the EIA Authority's Statements.

61. cf. Jay et al., Environmental impact assessment.

62. Anttonen, pers. comm; Matti Särkelä, Head of Office, Reindeer Herders' Association, Rovaniemi, e-mail correspondence with first author, March 14, 2016.

63. RHA, Guide to examining reindeer husbandry.

64. Anttonen, pers. comm.

65. 2014-Review, 49.

66. Hast and Jokinen, "Elinkeinojen yhteensovittaminen - tarkastelussa kaivostoiminta, poronhoito ja luontomatkailu", in Kaivos suomalaisessa yhteiskunnassa, eds. Tuija Mononen and Leena Suopajärvi (Rovaniemi, Lapland University Press, 2016).

67. cf. Rathwell et al., Bridging knowledge systems; Frank Vanclay et al., Social Impact Assessment: Guidance for assessing and managing the social impacts of projects (Ottawa, International Association for Impact Assessment, 2015), https://www.csrm.uq.edu.au/publications/socialimpact-assessment-guidance-for-assessing-and-managing-the-social-impacts-of-projects (Sept. 15, 2016).

68. MSAH, "Environmental Impact Assessment. Social and Health Impacts," Handbooks of the Ministry of Social Affairs and Health 1 (1999), http://julkaisut.valtioneuvosto.fi/ bitstream/handle/10024/71273/URN\%3aNBN\%3afi-fe201504225515.pdf?sequence=1 (Oct. 4, 2016).

69. For an overview of the Finnish spatial planning system, see Kokko et al., Sound Mining in the North, 27.

70. Pöyry, Meeting Minutes. The Kittilä mine has been built based on the mining, environmental and water permits (Interview Spatial Planner, March 4, 2015), with the mine facilities approved by the local government in an "extended building permit solution" (Rovaniemi Regional Administrative Court, Ruling 07/0036/1, Jan. 26, 2007).

71. Interview Spatial Planner, March 4, 2015.

72. Ismo Pölönen, "Mines in Land Use Plans. Discretion of the Municipalities in Directing the Mining Activities," Oikeus 45(1) (2016), 80.

73. Jääskeläinen \& Syrjänen, Land Use and Building Act, 202.

74. Sodankylä Municipality 2010, "Application of Kevitsa Mining Oy concerning extended building permit solution," Environmental Board March 26, 2010, http://sodankyla.ktweb.fi/ (May 21, 2016); Pyöry Finland, Plan of Assessment Extension of Kevitsa Mine (Oulu, Pöyry Finland, 2009) http://www.ymparisto.fi/download/noname/\%7B5AE6C14C-9710-45B39A14-86E53CE141FA\%7D/76834 (Oct. 12, 2016), 109.

75. Jorma Jantunen and Pekka Hokkanen, "Evaluation of the existing EIA legislation - how EIA procedures function in practice and areas needing improvement," Finnish Environment 18 (Helsinki, Ministry of the Environment, 2010), https:/helda.helsinki.fi/bitstream/handle/ 
10138/37983/SY_18_2010_YVA-lainsaadannon_toimivuusarviointi.pdf?sequence=1 (Oct. 4, 2016).

76. Mining Act 621/2011, dS 50, 52.4, 38, http://www.finlex.fi/en/laki/kaannokset/2011/ en20110621.pdf (Jan. 11, 2017).

77. Ibid., \34; Act on EIA, \13.

78. Ismo Pölönen, "Ympäristönäkökohtien ja paikallisten toimijoiden asema kaivoslain mukaisessa lupaharkinnassa", Lakimies 3 (2013).

79. Kokko et al 2014, Sound Mining in the North, 31. Ismo Pölönen, Environmental Impact Assessment Procedure - The Legal Status of EIA and Improvement Needs from an Environmental Effectiveness Perspective (Helsinki, Suomalainen Lakimiesyhdistys, 2007), 201; Pölönen et al., The effectiveness of the Finnish EIA system.

80. Pölönen, Environmental Impact Assessment Procedure, 162, 167.

81. Finnish Environment Institute, "Environmental information on mining projects: background information on mining legislation and environmental monitoring in certain mines", Reports of the Finnish Environment Institute 10 (2013), 24. Permalink: https://helda.helsinki.fi/ handle/10138/38469.

82. Pölönen, Ympäristönäkökohtien ja paikallisten toimijoiden asema, $431 \mathrm{ff}$.

83. Mining Authority, Provisions for the Safeguarding of Public and Private Interests: Suurikuusikko, March 4, 2016, Hearing Document; Mining Authority, Provisions for the Safeguarding of Public and Private Interests: Suurikuusikko, fune 24, 2014; Mining Authority, Provisions for the Safeguarding of Public and Private Interests: Kuotko, fune 24, 2014; Mining Authority, Provisions for Safeguarding of Public and Private Interests: Kevitsa, Fune 24, 2014.

84. Head of Reindeer Herding Cooperative, personal communication, April 20, 2015.

85. Pölönen, Ympäristönäkökohtien ja paikallisten toimijoiden asema.

86. cf. Jay et al., Environmental impact assessment; Sadler, Environmental Assessment in a Changing World; Cashmore et al., The role and functioning of environmental assessment.

87. cf. Rathwell et al., Bridging knowledge systems.

88. Angus Morrison-Saunders and Francois Retief, "Walking the sustainability assessment talk - Progressing the practice of environmental impact assessment (EIA)," Environmental Impact Assessment Review 36 (2012): 34.

89. Cashmore et al., The role and functioning of environmental assessment.

90. Angus Morrison-Saunders, Ross Marshall and Jos Arts, "EIA Follow-Up International Best Practice Principles", Special Publication Series 6 (Fargo, International Association for Impact Assessment, 2007), 1, http://www.iaia.org/uploads/pdf/SP6_1.pdf (Dec. 15, 2016).

91. cf. Finnish Ministry of the Environment, Arctic Environment Protection strategy; Renita Schuh, "Developing Guidelines for Incorporating Traditional Knowledge into the Environmental Impact Assessment Process", (Yellowknife, Mackenzie Valley Environmental Impact Review Board, 2005), http://www.reviewboard.ca/upload/ref_library/352_Schuh_Guide lines_for_Incorporating_Traditional_Knowledge_into_the_EIA_1184018866.PDF (Dec. 15, 2016). 